\title{
Optimization of Ceramic Shells for Contact with Reactive Alloys
}

\author{
Teresa P. Duarte ${ }^{1, a}$, Rui J. Neto ${ }^{2, b}$, Rui Félix ${ }^{2, c}$ and F. Jorge Lino ${ }^{1, d}$ \\ ${ }^{1,4}$ FEUP, Faculty of Engineering, University of Porto, R. Dr. Roberto Frias, 4200-465 Porto, \\ Portugal \\ ${ }^{2,3}$ INEGI, Institute of Mechanical Engineering and Industrial Management, R. Barroco 174, 4465- \\ 591 Leça do Balio, Portugal \\ atpd@fe.up.pt, ${ }^{b}$ rneto@inegi.up.pt, ${ }^{c}$ rfelix@inegi.up.pt, ${ }^{d}$ falves@fe.up.pt
}

Keywords: Casting, Ceramics, Titanium, Investment Casting.

\begin{abstract}
Companies are continuously under pressure to innovate their products and processes. In Portugal, there are already several examples of enterprises that have chosen research groups, associated to universities, to straighten collaboration seeking the development of new materials and advanced technological processes, to produce components with complex shapes, high surface quality, and others, at low cost, for continuously more demanding applications. Unfortunately, these cases are still a very small number, and many efforts have to be done to enlarge the collaboration university-companies. Ti and other reactive alloys are important groups of metals that are under intense and continuous research and development. For example, the high mechanical properties, low density, osteointegration behavior, corrosion resistance to fluids and tissues of the human body, the ability to be sterilized, and the possibility to obtain complex shapes, makes $\mathrm{Ti}$ a very attractive material for medical applications. The investment casting process, using lost wax or lost rapid prototyping models, allows designers a great amount of freedom and capacity to quickly produce castings of high dimensional accuracy and excellent surface quality suitable for different applications. Many of the castings obtained by this process are immediately ready for use, avoiding costly machining operations and joining processes, making the process very attractive to produce precision parts in $\mathrm{Ti}$ and other reactive alloys. However, the high reactivity of the $\mathrm{Ti}$ raises several compatibility problems with the traditional materials employed on the ceramic shells for casting steels and non ferrous alloys. The fragile surface layer obtained on the interface Ti-ceramic shell, result of the Ti reaction with oxygen and nitrogen of the shell, significantly reduces the mechanical properties of the cast parts, making them useless. The aim of the present work is the study of the interface properties of the Ti-ceramic shell, in order to be able to manufacture ceramic shells of low chemical reactivity for the investment casting process of reactive alloys, namely; titanium alloys, inconel, aluminotitanates, and others. Ceramic shells manufactured with calcium and yttria stabilized zirconia and other non reactive ceramics were employed and the metallic interface characterized in terms of microscopic and microhardness properties.
\end{abstract}

\section{Introduction}

Investment casting of titanium alloys is increasingly used in aeronautical and aerospatial construction and medical applications. For components that are under mechanical, fatigue, creep and thermal stresses, these alloys, such as TiAl6V4, and more recently, titanium aluminates, represent significant savings in weight, while providing the necessary static and dynamic strength and biocompatibility $[1,2]$. However, a broader application of these alloys is strongly limited by its higher cost, relative to competing materials, such as $\mathrm{Al}, \mathrm{Ni}, \mathrm{Co}$ and $\mathrm{Fe}$ alloys, and also by the high reactivity of these alloys with almost all ceramic materials currently applied in precision foundry. Cast these alloys requires special equipment and conditions, and special knowledge and techniques that are not published, since titanium is very reactive in the molten state. Coating the pattern with the usual ceramic slurries (based on silica and aluminosilicates) generates a reaction with the $\mathrm{Ti}$ alloys, with a formation of a 0,3 - 0,6 $\mathrm{mm}$ very hard, fissured and weak reaction layer, called alpha- 
case [3]. This surface layer, result of the Ti reaction with the metallic oxides of the ceramic shells, is composed by fragile, intermetallics compounds that significantly reduce the mechanical properties of the casted parts [4]. To overcome this problem, titanium alloys should be poured into special ceramic shells that avoid or significantly reduces this reaction. To select the most suitable ceramics it is necessary to take into account the standard free energy change of oxides formation. Ceramics, such as $\mathrm{CaO}, \mathrm{ZrO}_{2}, \mathrm{Y}_{2} \mathrm{O}_{3}$ and $\mathrm{ThO}_{2}$ have been adopted for mold materials, due to the standard free energy changes of oxides formation that are more negative than $\mathrm{TiO}_{2}$ as one can see in Fig. $1[3,5]$. The only oxide that is placed above the $\mathrm{TiO}_{2}$ line is $\mathrm{SiO}_{2}$, indicating that this oxide is not suitable to be incorporated in the shells to cast Ti. Fig. 2 presents an example of one Ti part obtained by investment casting.

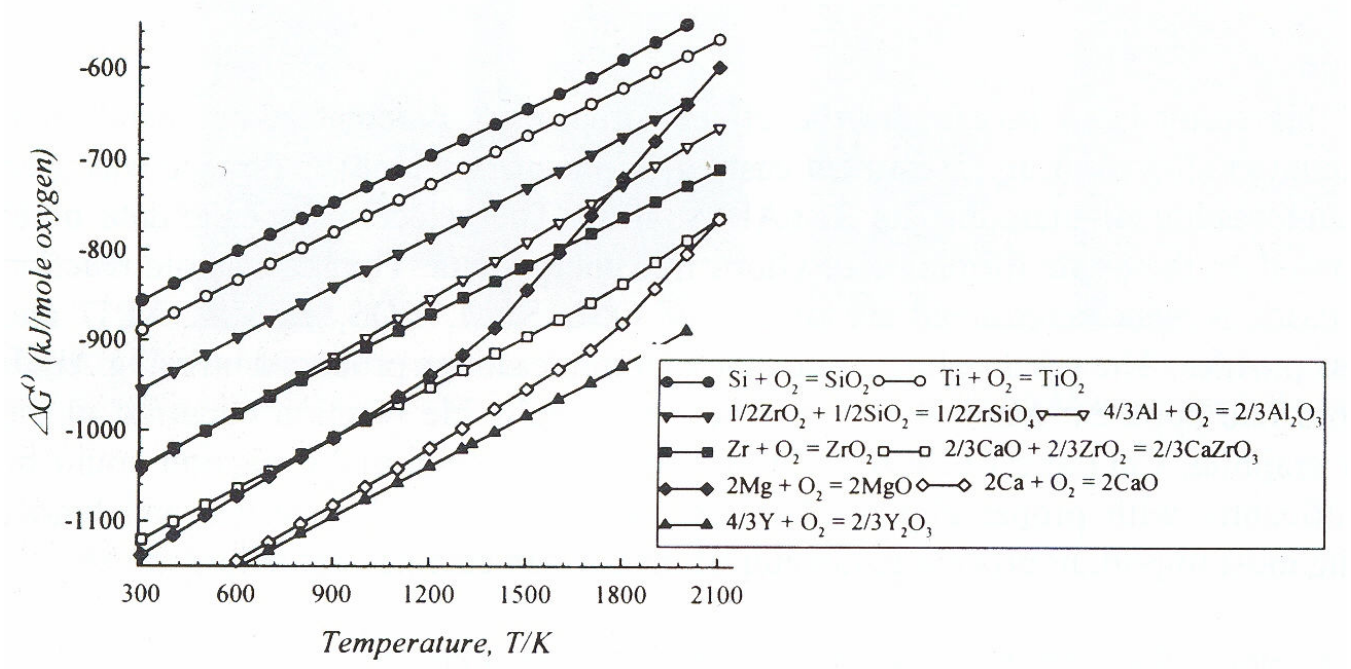

Fig. 1 Standard free energy variation of oxides formation with the temperature [5].

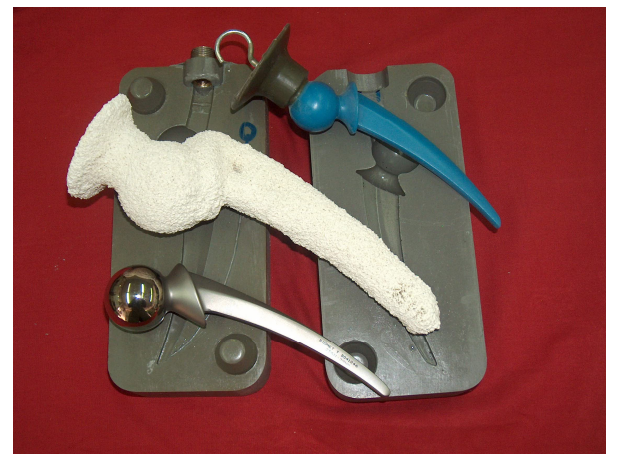

Fig. 2 From the top to down: Wax pattern with the pouring system, ceramic shell and Ti casted part placed over the composite mould used to inject the wax model.

\section{Experimental work}

Shells Production: In order to test the reactivity of different ceramic materials with $\mathrm{Ti}$ and its alloys, ceramic shells were manufactured over wax models (cylinders of $10 \mathrm{~mm}$ diameter and 15 $\mathrm{mm}$ height), using a process developed at INEGI (Institute of Mechanical Engineering and Industrial Management, Portugal). Table 1 indicates the ceramics and binder employed. The selection of these ceramic raw materials was done considering the data of Fig. 1 and the availability of the respective commercial products. After manufacturing the entire shell layers the ceramic moulds were sintered for $2 \mathrm{~h}$ at $1100^{\circ} \mathrm{C}$.

Melting and Casting: Melting and casting at IFIMUP - Instituto de Física dos Materiais da Universidade do Porto, of the selected alloy, Ti10V2Fe3Al, was performed in a vacuum levitation cold crucible, inside a high frequency induction furnace. The pressure was $5 \times 10^{-4} \mathrm{mbar}$, 
subsequently filled with high purity argon (99,9999\%) at 800-900 mbar. After melting, pouring, and cooling for 10 minutes the mold was removed from the furnace.

Metal-Mold Reaction: The reaction layer of the castings was characterized by microstructural analysis of the metal-mold interface, using an optical microscope (Olympus PMG3) and a scanning electron microscope (Jeol JSM-6301F). The microhardness (HV) profile (Shimadzu HVM-2000) of this region was also obtained. The samples were polished using Struers consumables and equipment, accordingly to the suggestions indicated in ref. [7], and followed by etching with Kroll's reagent: 1-3ml HF, 2-6 $\mathrm{ml} \mathrm{HNO}_{3}, \mathrm{H}_{2} \mathrm{O}$ to $1000 \mathrm{ml}$.

Table 1 - Composition of the ceramic shells first layer slurry.

\begin{tabular}{|c|c|}
\hline Ceramic flours (all particles under $45 \mu \mathrm{m})$ & Binder [6] \\
\hline Yttria stabilized Zirconia $\left(\mathrm{ZrO}_{2}-6 \% \mathrm{wt} \mathrm{\textrm {Y } _ { 2 } \mathrm { O } _ { 3 } )}\right.$ & Silica based \\
\hline Calcia stabilized Zirconia $\left(\mathrm{ZrO}_{2}-3 \% \mathrm{wt} \mathrm{CaO}\right)$ & Silica based \\
\hline Yttria $\left(\mathrm{Y}_{2} \mathrm{O}_{3}\right)$ & Silica based \\
\hline
\end{tabular}

\section{Results and discussion}

The microstructures obtained are shown in Fig. 3. As one can see the samples surface (right side) characteristics are very different from the inner microstructure, however the microstructure of the nucleus is similar for all the three cases. Fig. 4 presents the microhardness profile of this region.

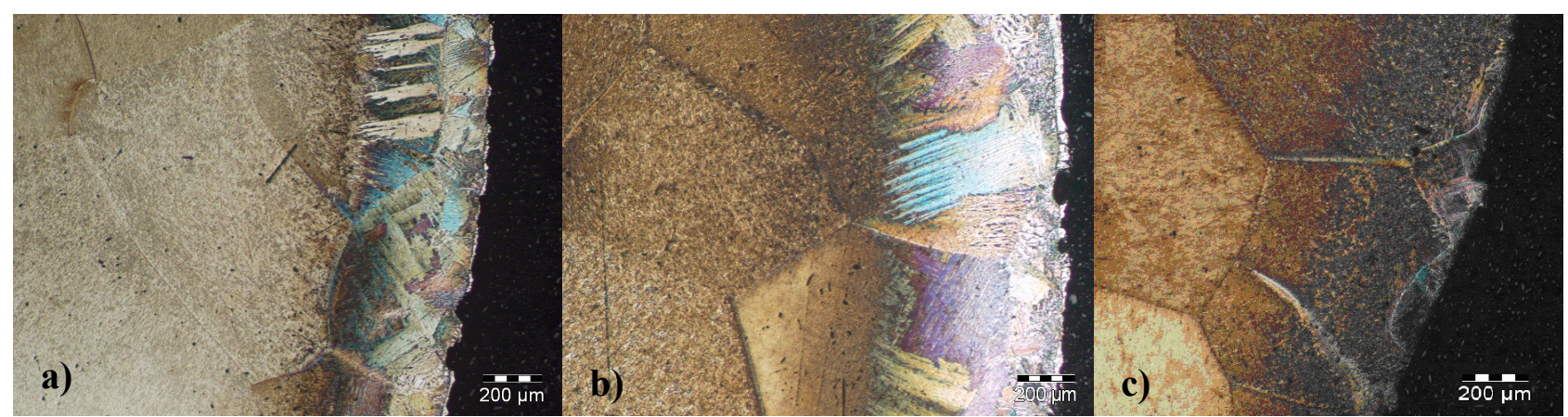

Fig. 3 Microstructure of the Ti10V2Fe3Al alloy casted in: a) $\mathrm{ZrO}_{2}-\mathrm{Y}_{2} \mathrm{O}_{3}$ ceramic mould, b) $\mathrm{ZrO}_{2-}$ $\mathrm{CaO}$ ceramic mould and c) $\mathrm{Y}_{2} \mathrm{O}_{3}$ ceramic mould.

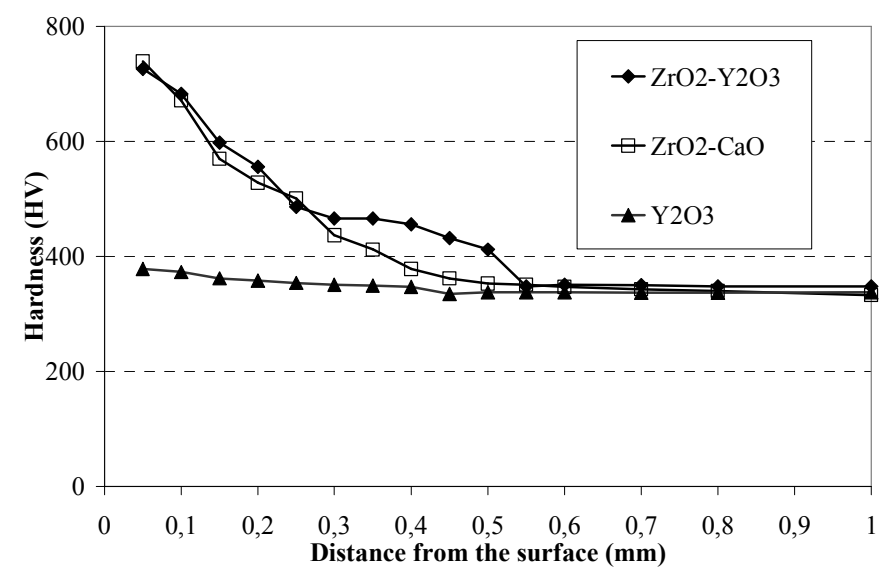

Fig. 4 Microhardness profiles as a function of the distance from the surface for mold materials.

The microhardness profiles of the samples casted in $\mathrm{ZrO}_{2}-\mathrm{Y}_{2} \mathrm{O}_{3}$ and $\mathrm{ZrO}_{2}-\mathrm{CaO}$ mould are similar. The depth of the alpha-case is around $0,55 \mathrm{~mm}$ for $\mathrm{ZrO}_{2}-\mathrm{CaO}$ ceramic mould and $0,45 \mathrm{~mm}$ for $\mathrm{ZrO}_{2}-\mathrm{Y}_{2} \mathrm{O}_{3}$. $\mathrm{Y}_{2} \mathrm{O}_{3}$ shell almost does not produce alpha-case because microhardness values (around 350HV) are kept constant independently of the surface distance. To explain these different behaviors, the samples were observed by SEM and EDS (Figs. 5 and 6). The chemical composition (Fig. 6) was analyzed in the areas marked on the photomicrographs of Fig. 5 (Z). Although the 
differences detected on the microstructure, the chemical composition was kept the same and corresponds to the main elements present in the alloy: Ti, V, Al and Fe (Fig. 6). The presence of O, $\mathrm{N}, \mathrm{Si}, \mathrm{Zr}, \mathrm{Ca}$ and $\mathrm{Y}$ was not detected by the used facilities.

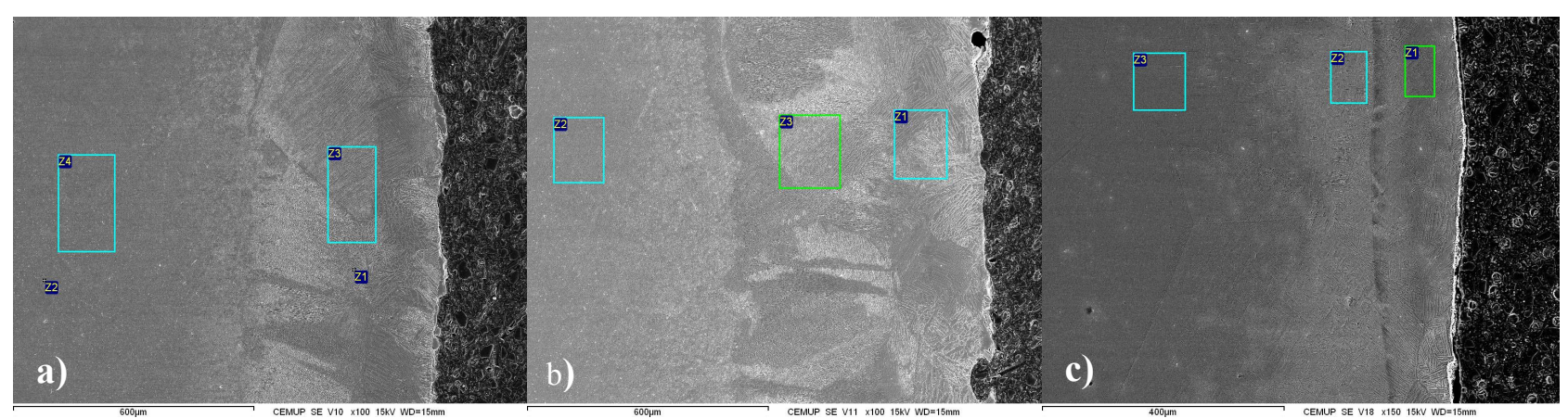

Fig. 5 Microstructure of Ti10V2Fe3Al alloy casted in ceramic moulds of: a) $\mathrm{ZrO}_{2}-\mathrm{Y}_{2} \mathrm{O}_{3}$, b) $\mathrm{ZrO}_{2}-$ $\mathrm{CaO}$ and c) $\mathrm{Y}_{2} \mathrm{O}_{3}$.

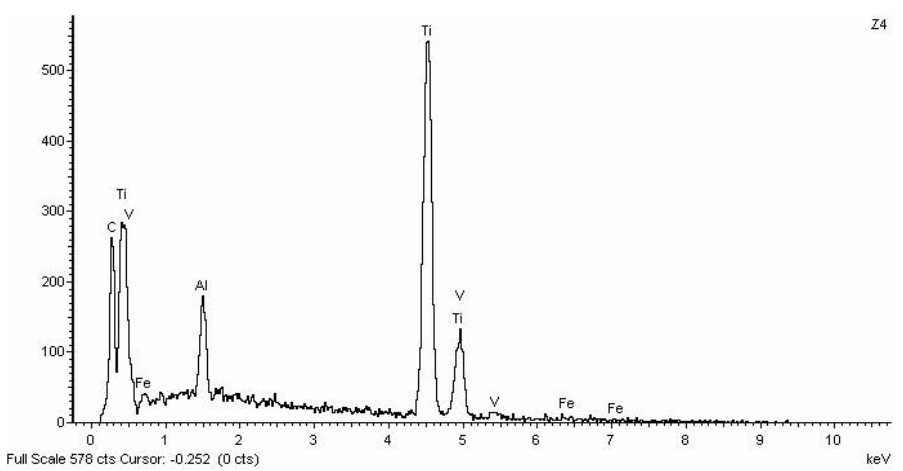

Fig. 6 EDS analysis of Ti10V2Fe3Al samples.

In order to identify the causes to the microhardness values obtained, the microstructures were examined at a higher magnification (Figs. 7 - 9).

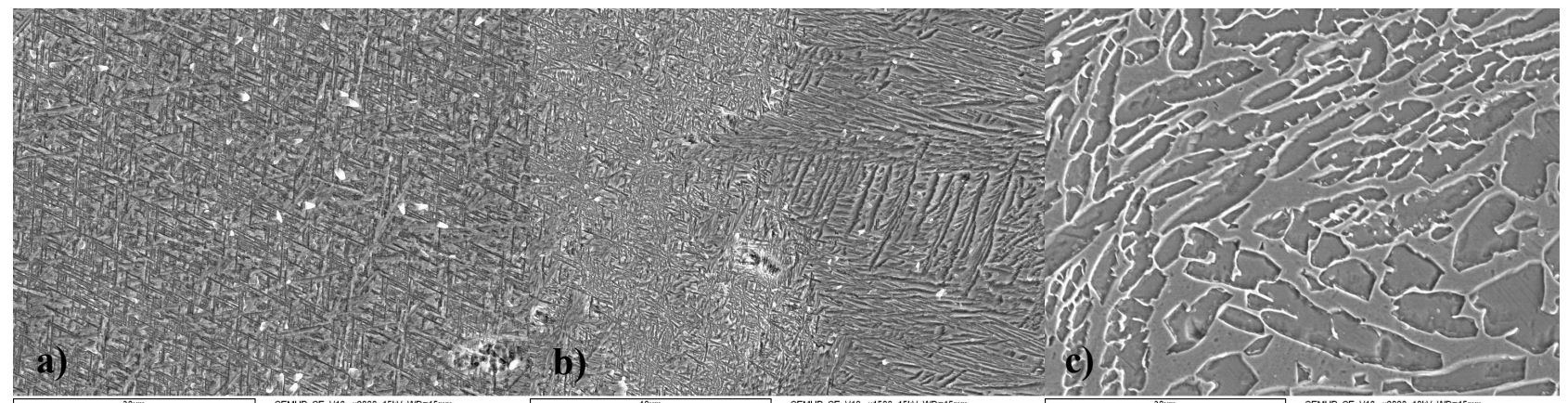

Fig. 7 Microstructure of Ti10V2Fe3Al alloy casted in a $\mathrm{ZrO}_{2}-\mathrm{Y}_{2} \mathrm{O}_{3}$ mold: a) inner region, b) transition zone and c) surface.

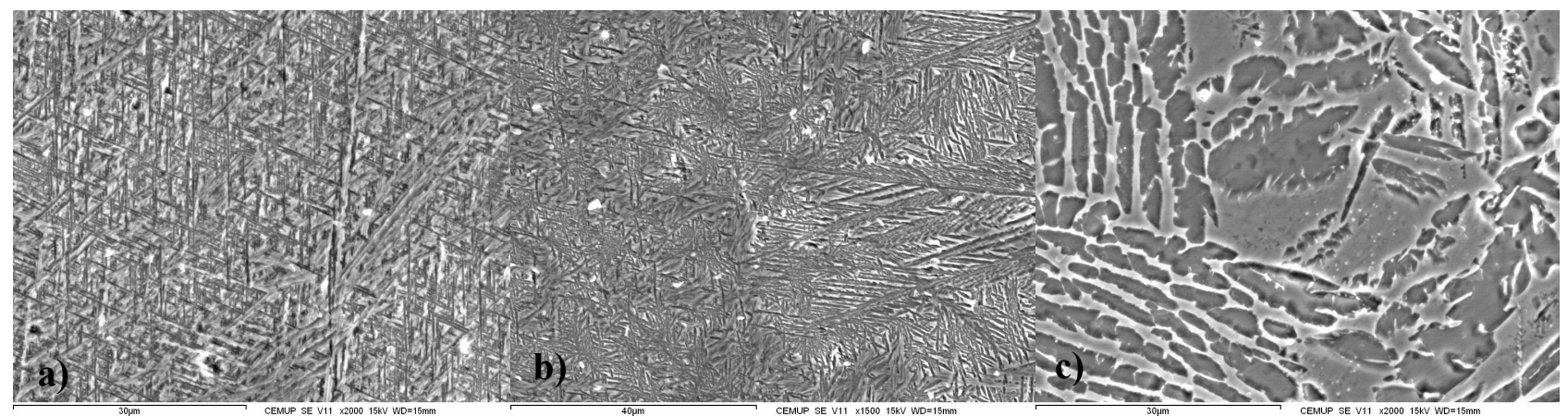

Fig. 8 Microstructure of Ti10V2Fe3Al alloy casted in a $\mathrm{ZrO}_{2}-\mathrm{CaO}$ mold: a) inner region, b) transition zone and c) surface. 


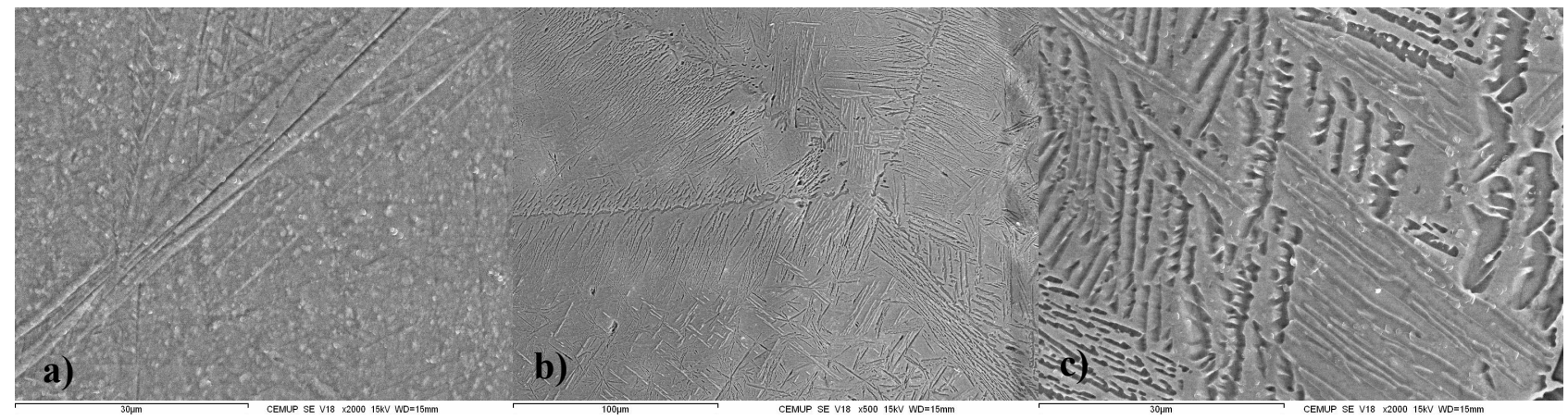

Fig. 9 Microstructure of Ti10V2Fe3Al alloy casted in a $\mathrm{Y}_{2} \mathrm{O}_{3}$ mold: a) inner region, b) transition zone and c) surface.

In Ti10V2Fe3Al samples casted in yttria or calcia stabilized zirconia there is a clear transition between the two areas (Figs 7 and $8 \mathrm{~b}$ )). This transition region does not appear in the sample casted in the yttria ceramic mold (Fig. 9).

\section{Conclusions}

Investment casting of reactive alloys, such as $\mathrm{Ti}$, is a challenging process due to the high reactivity of these materials with the atmosphere and ceramic molds. To develop a process capable to produce sound parts without alpha-case, the authors produced and tested different ceramic compositions that conducted to the following conclusions:

- It is possible to obtain ceramic shells using $\mathrm{ZrO}_{2}-\mathrm{Y}_{2} \mathrm{O}_{3}, \mathrm{ZrO}_{2}-\mathrm{CaO}$ and also $\mathrm{Y}_{2} \mathrm{O}_{3}$ aggregated with a silica based binder.

- $\mathrm{CaO}$ stabilized $\mathrm{ZrO}_{2}$ or $\mathrm{Y}_{2} \mathrm{O}_{3}$ stabilized $\mathrm{ZrO}_{2}$ employed in the first layer of the ceramic shells, produces similar alpha case depths, around 0,45 to $0,55 \mathrm{~mm}$.

- The alpha-case layer does not seem to be caused by chemical composition changes at the surface analyzed by EDS. In the future other techniques must be used.

- $\quad \mathrm{Y}_{2} \mathrm{O}_{3}$ ceramic mold almost does not promote the formation of alpha-case and can be regarded as a promising ceramic mold material for the investment casting of Ti alloys.

- Maximum alpha-case microhardness is about $730 \mathrm{HV}$ at both samples surface (casted in $\mathrm{ZrO}_{2}-\mathrm{Y}_{2} \mathrm{O}_{3}$ and $\mathrm{ZrO}_{2}-\mathrm{CaO}$ moulds).

\section{References}

[1] M. Niinomi, J. C. Williams in Properties and Applications of Ti: Current Status and Future Needs, Proc. of the 10th World Conf. on Titanium, Hamburg, Vol. I, p. 95 - 110 (2003)

[2] Metals Handbook, Vol. 2 "Properties and Selection: Nonferrous Alloys and Special-Purpose Materials", ASM International (1990)

[3] Si-Young Sung, Young-Jig Kim in Alpha-case formation mechanism on titanium investment castings, Materials Science and Engineering A 405, p. 173-177 (2005)

[4] H. S. Ding, J. J. Guo, J. Jia, H. Z. Fu in Thermodynamic and Kinetic Consideration of Selecting Mould Materials for Casting Titanium Alloys, Proc. of the 10th World Conf. on Titanium, Hamburg, Vol. I, p. 439 - 446 (2003)

[5] M.-G. Kim, et al. in Effects of Process Parameters on Metal-Mold Reaction of Ti and Ti-6Al4V Alloy, Proc. of the 10th World Conf. on Titanium, Hamburg, Vol. I, p. 447 - 454 (2003)

[6] Teresa P. Duarte in Fabrico Rápido de Ferramentas por Fundição de Precisão, PhD Thesis, FEUP, DEMEGI (2002)

[7] Metals Handbook, Vol. 9 "Metallography and Microstructures”, ASM International (1985) 